\title{
Kualitas benih dan pertumbuhan bibit cabai (Capsicum frutescens 1.) pada perlakuan suhu dan wadah penyimpanan yang berbeda
}

\author{
(Seeds quality and seedling growth of chilli (Capsicum frutescents l.) on difference \\ temperature and storage containers) \\ D. B. Taghfir, S. Anwar, B. A. Kristanto \\ Agricultural Department, Faculty of Animal and Agricultural Sciences, Diponegoro University \\ Tembalang Campus, Semarang 50275 - Indonesia \\ Corresponding E-mail:dimastaghfirr@gmail.com
}

\begin{abstract}
Setting the temperature of the storage space of seeds and storage containers will greatly affect the quality of the seed. The aim of this research was to study the effect of temperature treatment, storage container and their interaction on seed quality and seedling growth of chilli. The study was conducted in Jetis Village and Laboratory of Plant Physiology and Breeding, Faculty of Animal and Agricultural Sciences, Diponegoro University from January to June 2017. The study was conducted using nesting experiments on the basis of Completely Randomized Design (RAL). The first factor was Storage Temperature $\left(\mathrm{R} 1=\right.$ Room Temperature $24-29^{\circ} \mathrm{C}, \mathrm{R} 2=$ Refrigerator Temperature $\left.5^{\circ} \mathrm{C}\right)$ and second factor was storage container nested at storage temperature that was $(\mathrm{P} 1=$ Alumunium foil, $\mathrm{P} 2=$ Paper and $\mathrm{P} 3=$ Plastic). Each treatment had 5 replications and each replication consisted of 100 seeds, so there were 30 experimental units. The data were analyzed by using analysis of variance (ANOVA) and continued with test of HSD (Honesty Significant Difference) 5\% significance level. The results showed that the storage temperature $\left(5^{\circ} \mathrm{C}\right)$ temperature increased the temperature and the seed vigor index was larger than the room temperature $\left(28^{\circ} \mathrm{C}\right)$, the aluminum foil packaging produced the maximum growth potential and germination rate was higher than the plastic and paper packaging but there was no different growth rate and index vigor. Low storage space temperatures $\left(5^{\circ} \mathrm{C}\right)$ can not maintain maximum seed quality where the 4 parameters were still below the standard quality of the seed. Seeds stored in low temperature $\left(5^{\circ} \mathrm{C}\right)$ rooms produced fresh weight and dry weight of seedlings larger than high temperature $\left(28^{\circ} \mathrm{C}\right)$, but the number of leaves, seed height and hypothetical vigor index were not significantly different. The aluminum foil packaging produced fresh weight and dry weight of seeds higher than plastic and paper packaging. However, the number of leaves, the height of seed and the hypothetical vigor index were not significantly different.
\end{abstract}

Keywords : Temperature, container store, seeds quality, seedling growth, chilli.

\begin{abstract}
ABSTRAK
Pengaturan suhu ruang simpan benih dan wadah simpan akan sangat mempengaruhi kualitas benih. Penelitian bertujuan untuk mengkaji pengaruh perlakuan suhu, wadah simpan dan interaksinya terhadap kualitas benih dan pertumbuhan bibit cabai rawit. Penelitian dilakukan di Desa Jetis dan Laboratorium Fisiologi dan Pemuliaan Tanaman, Fakultas Peternakan dan Pertanian Universitas Diponegoro dari bulan Januari sampai Juni 2017. Penelitian dilakukan menggunakan percobaan tersarang dengan dasar rancangan acak lengkap (RAL). Faktor pertama yaitu suhu penyimpanan $\left(\mathrm{R} 1=\mathrm{Suhu}\right.$ ruangan $24-29{ }^{\circ} \mathrm{C}$, $\mathrm{R} 2=$ Suhu kulkas $5{ }^{\circ} \mathrm{C}$ ) dan faktor kedua adalah wadah simpan yang tersarang pada suhu penyimpanan yaitu ( $\mathrm{P} 1=$ Alumunium foil, $\mathrm{P} 2=$ Kertas dan $\mathrm{P} 3=$ Plastik). Setiap perlakuan memiliki 5 kali ulangan dan setiap ulangan terdiri dari 100 biji, sehingga terdapat 30 unit percobaan. Data dianalisis dengan menggunakan metode analisis of varians (ANOVA) dan dilanjutkan dengan uji Beda Nyata Jujur (BNJ) taraf signifikansi $5 \%$. Hasil penelitian menunjukkan bahwa suhu ruang penyimpanan $\left(5^{\circ} \mathrm{C}\right)$ menghasilkan
\end{abstract}


kecepatan tumbuh dan indeks vigor lebih besar dibanding suhu ruangan $\left(28^{\circ} \mathrm{C}\right)$, kemasan alumunium foil menghasilkan potensi tumbuh maksimum dan daya berkecambah lebih tinggi dibanding kemasan plastik dan kertas namun tidak berbeda kecepatan tumbuh dan indeks vigor. Suhu ruang penyimpanan rendah $\left(5^{\circ} \mathrm{C}\right)$ tidak dapat mempertahankan kualitas benih secara maksimal dimana 4 parameter tersebut masih dibawah standar kualitas benih. Benih yang disimpan dalam ruangan dengan suhu rendah $\left(5^{\circ} \mathrm{C}\right)$ menghasilkan berat basah dan berat kering bibit lebih besar dibanding suhu tinggi $\left(28^{\circ} \mathrm{C}\right)$, namun jumlah daun, tinggi bibit dan indeks vigor hipotetik tidak berbeda. Kemasan alumunium foil menghasilkan berat basah dan berat kering bibit lebih tinggi dibanding kemasan plastik dan kertas. Namun jumlah daun, tinggi bibit dan indeks vigor hipotetik tidak berbeda.

Kata Kunci: Suhu dan wadah simpan, kualitas benih dan pertumbuhan bibit, cabai.

\section{PENDAHULUAN}

Salah satu faktor determinan yang mempengaruhi ketersediaan benih adalah penyimpanan benih. Penyimpanan benih bertujuan untuk mempertahankan kualitas benih. Petani harus mampu melakukan penyimpanan benih secara benar, agar tetap dapat melakukan kegiatan budidaya apabila terjadi kelangkaan ketersediaan benih di pasaran, petani tetap dapat melakukan kegiatan budidaya cabai. Penyimpanan benih cabai rawit yang baik, harus memperhatikan suhu dimana benih disimpan dan wadah simpan yang sesuai.

Suhu penyimpanan berpengaruh terhadap kualitas benih. Viabilitas benih setelah mengalami penyimpanan dipengaruhi oleh kadar air benih sebelum disimpan, suhu dan kelembaban nisbi ruangan selama penyimpanan. Suhu penyimpanan yang rendah maka laju respirasinya rendah sehingga periode simpan benih dapat dipertahankan lebih panjang (Yuniarti dan Djaman, 2015). Suhu yang rendah menyebabkan respirasi berjalan lambat dibanding suhu yang tinggi sehingga kadar air benih terjaga. Suhu 4-9 ${ }^{\circ} \mathrm{C}$ pada kulkas dapat menyebabkan benih mengalami pengerasan kulit yang menyebabkan dormansi benih menjadi lebih lama sehingga waktu pematahan after ripening menjadi lebih lama (Rahayu dan widajati, 2007).

Wadah simpan atau kemasan memiliki peranan penting dalam mempertahankan kualitas benih. Wadah simpan berfungsi sebagai pengendalian laju transpirasi, respirasi, melindungi benih dari mikroba dan jamur (Sembiring, 2009). Jenis bahan wadah simpan yang digunakan berpengaruh terhadap mutu benih yang disimpan. Wadah simpan yang digunakan dalam penelitian yaitu aluminium foil, kertas dan plastik, masing - masing memiliki kelebihan dan kekurangan. Aluminim foil merupakan wadah simpan yang paling banyak digunakan untuk menyimpan benih. Kemasan aluminium foil memiliki kelebihan yaitu kedap udara sehingga kelembaban pada benih selama penyimpanan tetap terjaga. Kemasan penyimpanan yang tidak kedap udara menyebabkan kadar air benih menjadi tinggi, apabila kelembaban nisbi ruang penyimpanan sangat tinggi atau menjadi rendah atau menurun apabila kelembaban nisbi ruang penyimpanan sangat rendah akibat dari benih yang mengadakan keseimbangan kadar air dengan udara sekitarnya. Kemasan penyimpanan yang kedap udara mampu mempertahankan kadar air benih (Purba dkk., 2013).

Plastik merupakan bahan kemasan yang memiliki sifat resisten terhadap kelembaban, kuat terhadap tekanan dan tidak mudah pecah atau sobek (Rahayu dan Widajati, 2007). Penyimpanan benih dengan plastik pada suhu kulkas dapat mempertahankan vigor benih sampai 15 minggu (Rahayu dan Widajati, 2007). Kemasan simpan kertas memiliki sifat yang sensitif terhadap air dan mudah dipengaruhi oleh kelembaban udara lingkungan (Dwiari dkk., 2008).

Cabai rawit (Capsicum frutescens $\mathrm{L}$ ) merupakan jenis sayuran buah yang memiliki 2030 spesies, (Rukmana, 2006). Cabai rawit berumur panjang, dapat hidup sampai umur satu tahun dan dapat dipanen pada umur 4-5 bulan (Alif, 2017). Kandungan gizi dan vitamin pada $100 \mathrm{~g}$ cabai rawit segar antara lain yaitu kalori (103,00 kal.), protein (4,70 g), lemak $(2,40 \mathrm{~g})$, karbohidrat (19,90 g), Kalsium (45 mg), Fosfor (85 mg), Vitamin A (11.050 SI), zat besi (2,50 mg) Vitamin B1 (0,08 mg), Vitamin C (70 mg), dan air 
(71,20 g) (Rukmana, 2006).

Tanaman cabai rawit memiliki potensi ekonomi yang baik untuk dimanfaatkan dalam bisnis karena kebutuhan akan cabai tinggi dengan harga tinggi. Harga cabai rawit dapat berubah setiap saat apabila pasokan cabai sedikit dengan jumlah yang selalu tinggi sehingga menyebabkan harganya naik. Menurut outlook Direktorat Jenderal Tanaman Pangan (2016) terjadi peningkatan produksi cabai nasional 843.998 ton di tahun 2016 menjadi 887.260 ton pada tahun 2017.

Benih cabai rawit yang bermutu sangat dibutuhkan oleh para petani. Benih bermutu akan menghasilkan pertumbuhan tanaman yang baik dan menghasilkan produksi yang tinggi. Salah satu upaya mempertahankan mutu benih yaitu dengan melakukan penyimpanan benih dengan cara yang tepat.

Penelitian bertujuan untuk mengkaji pengaruh perlakuan suhu dan wadah penyimpanan benih terhadap kualitas benih dan pertumbuhan bibit cabai rawit.

\section{MATERI DAN METODE}

Penelitian telah dilaksanakan pada 25 Januari sampai 26 Juni 2017 di Desa Jetis, Kecamatan Bandungan Kabupaten Semarang dan Laboratorium Fisiologi dan Pemuliaan Tanaman, Fakultas Peternakan dan Pertanian, Universitas Diponegoro.

\section{Materi Penelitian}

Alat yang digunakan dalam penelitian ini adalah sekop, kulkas, baskom, bekker glass 1000 $\mathrm{ml}$, hand sprayer, alat perekat, polybag, label dan alat tulis. Bahan yang digunakan yaitu benih cabai rawit, tanah, plastik, kertas aluminium foil, pupuk npk dan pupuk organik cair.

\section{Rancangan penelitian}

Penelitian dilakukan menggunakan percobaan tersarang dengan dasar Rancangan Acak Lengkap (RAL). Faktor pertama yaitu suhu penyimpanan $\left(\mathrm{R} 1=\right.$ Suhu ruangan $24-29^{\circ} \mathrm{C}, \mathrm{R} 2=$ Suhu $5{ }^{\circ} \mathrm{C}$ ) dan faktor kedua adalah wadah simpan yang tersarang pada Suhu Penyimpanan yaitu (P1 $=$ Aluminium foil, $\mathrm{P} 2=$ Kertas, $\mathrm{P} 3=$ Plastik). Setiap perlakuan memiliki 5 kali ulangan dan setiap ulangan terdiri dari 100 biji, sehingga terdapat 30 unit percobaan.

\section{Prosedur penelitian}

Penelitian dilakukan dengan beberapa tahapan, yaitu persiapan penelitian, persiapan benih cabai rawit, pengemasan benih cabai rawit, penyimpanan benih cabai rawit, pengujian viabilitas dan vigor, pengamatan pertumbuhan bibit.

Persiapan benih cabai rawit, penelitian dilakukan dengan menyiapkan benih cabai rawit yang dibeli dari toko pertanian di Ambarawa.

Benih dihitung sebanyak 100 biji dan dimasukkan ke dalam wadah sesuai perlakuan yaitu menggunakan aluminium foil, kertas dan plastik. Kemasan kertas ditutup menggunakan lem kertas, kemasan plastik ditutup menggunakan zipper dan aluminium foil direkatkan menggunakan isolasi.

Benih yang sudah dikemas diletakkan pada baskom kotak dan disimpan pada suhu kulkas (5 $\left.{ }^{\circ} \mathrm{C}\right)$ dan suhu ruangan $\left(24-29{ }^{\circ} \mathrm{C}\right)$. Benih disimpan selama 3 bulan sesuai dengan penyimpanan standard benih.

Setelah benih disimpan selama 3 bulan, diuji viabilitas dan vigor masing-masing menggunakan 25 benih. Uji viabilitas benih dilakukan dengan menyemai benih pada media tanah yang bebas dari penyakit, memiliki porositas yang sesuai yaitu aerasi dan drainasenya baik. Uji vigor benih dilakukan dengan cara memasukkan benih kedalam kain kassa kemudian diikat menggunakan benang dan direndam kedalam aquades selama 2 jam dengan suhu $60{ }^{\circ} \mathrm{C}$. Setelah 2 jam direndam, kemudian benih dikecambahkan kedalam media tanah. Setiap hari dilakukan pengamatan jumlah kecambah yang normal maupun yang abnormal. Kecambah normal memiliki ciri seperti hipokotil dan epikotil berkembang baik, plumula normal dan sistem perakaran baik. Kemudian tanaman yang tumbuh baik dipindahkan ke pot plastik dengan media tanah.

Pengamatan pertumbuhan bibit, dilakukan dengan parameter yang diamati yaitu tinggi tanaman, jumlah daun berat basah dan berat kering. Setiap hari bibit diamati pertumbuhannya sampai berumur 4 minggu.

\section{Cara Pengukuran Parameter Kualitas Benih}


Jumlah benih yang berkecambah digunakan untuk menghitung potensi tumbuh maksimal (PTM), daya berkecambah (DB), kecepatan tumbuh perkecambahan (Kct) dan indeks vigor (IV) dan indeks vigor hipotetik (IVH) (ISTA, 2007 dan Ekowahyuni dkk., 2012).

$$
\text { PTM }=\frac{\sum \text { Kecambah hidup (Normal+Abnormal) }}{\sum \text { Benih yang dikecambahkan }} \times 100
$$$$
\mathrm{DB}=\frac{\sum \text { K ecambah hidup (Normal) }}{\sum \text { Benih yang dikecambahkan }} \times 100 \%
$$

$$
\mathrm{KcT}=\frac{G 1}{\mathrm{D} 1}+\frac{G n}{\mathrm{Dn}}
$$

\section{$G=$ Jumlah Benih}

$D=$ Waktu yang bersesuaian dengan $G$

$$
\text { IV }=\frac{\text { Jumlah benih yang tumbuh pada hit ke } 1}{\text { Jumlah Benih }}
$$

Hit ke 1 = Jumlah kecambah normal hari ke-7

\section{Cara Pengukuran Parameter Pertumbuhan Bibit}

Parameter pertumbuhan bibit, mencakup: tinggi tanaman diamati dengan cara diukur menggunakan penggaris dari leher akar sampai ujung titik tumbuh. Produksi berat kering tanaman diamati dengan menimbang berat kering tanaman setelah dioven.

Perhitungan Indeks Vigor Hipotetik (IVH) menggunakan rumus sebagai berikut (Ekowahyuni dkk., 2012):

$$
\mathrm{IVH}=\frac{(\log \mathrm{JD}+\log \mathrm{TT}+\log \mathrm{BB}+\log \mathrm{BK})}{\log \mathrm{T}}
$$

$\mathrm{JD}=$ Jumlah daun

$\mathrm{TT}=$ Tinggi tanaman

$\mathrm{BB}=$ Berat basah

$\mathrm{BK}=$ Berat kering

\section{HASIL DAN PEMBAHASAN}

\section{Kualitas Benih}

Kualitas benih mencakup potensi tumbuh maksimum (PTM), daya berkecambah (DB), kecepatan tumbuh (KcT) dan indeks vigor (IV) Benih. Parameter tersebut merupakan acuan untuk menilai benih memiliki kualitas yang baik atau tidak.

\section{Potensi tumbuh maksimum (PTM)}

Hasil analisis ragam menunjukkan bahwa tidak terdapat pengaruh faktor suhu $(\mathrm{P}>0,05)$ terhadap potensi tumbuh maksimum benih cabai tetapi terdapat pengaruh faktor wadah penyimpanan $(\mathrm{P}<0,05)$ terhadap potensi tumbuh maksimumbenih cabai (Tabel 1). Perlakuan suhu ruangan $28^{\circ} \mathrm{C}(\mathrm{R} 1)$ tidak berbeda nyata dengan perlakuan suhu kulkas $5^{\circ} \mathrm{C}$ (R2) dengan nilai potensi tumbuh maksimum $59,73 \%$ dan $66,80 \%$. Benih yang disimpan menggunakan aluminium foil (P1) menunjukkan potensi tumbuh maksimum tertinggi yaitu $66,80 \%$ dan berbeda dengan wadah simpan ketas (P2) dan plastik (P3), tetapi wadah simpan ketas dan plastik tidak berbeda dengan potensi tumbuh maksimum masing-masing sebesar 59,60\% dan 54,40\%.

Suhu ruang simpan berpengaruh terhadap respirasi dan penguapan benih. Suhu ruang $5^{\circ} \mathrm{C}$ menyebabkan enzim yang terkandung dalam benih menjadi kurang aktif, sehingga menyebabkan penurunan proses respirasi. Penurunan proses respirasi berakibat penurunan aktivitas degradasi kandungan karbohidrat, protein dan lemak biji, sehingga kandungan air benih relatif tidak berubah. Suhu ruang kulkas $5^{\circ} \mathrm{C}$ juga menyebabkan kulit biji menjadi lebih tebal dan keras. Menurut Rahayu dan Widajati (2007), bahwa suhu kulkas $4-9{ }^{\circ} \mathrm{C}$ mengakibatkan benih mengalami pengerasan kulit yang menyebabkan dormansi benih menjadi lebih lama. Yuniarti dan Djaman (2015) menyatakan bahwa suhu penyimpanan yang rendah menurunkan laju respirasi benih, sehingga periode simpan benih dapat dipertahankan lebih panjang. Meskipun penurunan respirasi dan kadar air pada ruangan $28^{\circ} \mathrm{C}$ lebih besar, namun belum menurunkan potensi tumbuh maksimum. Menurut Kartono (2004), bahwa benih dengan kadar air 8-10\% disimpan pada suhu ruangan baik di bawah maupun di atas $20^{\circ} \mathrm{C}$ selama 6 bulan mempunyai daya tumbuh benih tidak berbeda. Indartono (2011) menambahkan bahwa perlakuan suhu ruangan belum berpengaruh terhadap daya berkecambah setelah benih disimpan selama tiga 
Tabel 1. Potensi Tumbuh Maksimum (PTM), Daya Berkecambah (DB), Kecepatan Tumbuh (KcT) dan Indeks Vigor (IV) Benih Cabai Rawit pada Perlakuan Suhu dan Wadah Penyimpanan yang Berbeda.

\begin{tabular}{lcccc}
\hline & PTM & DB & KcT & IV \\
\hline \multicolumn{1}{c}{ UJI F } & $0,26^{\mathrm{ns}}$ & $0,34^{\mathrm{ns}}$ & $7,53^{*}$ & $12,18^{*}$ \\
\hline R1 ( Suhu Ruang $\left.28^{\circ} \mathrm{C}\right)$ & $\ldots . \% \ldots$ & $\ldots . \% \ldots$ & $\ldots . \% / \mathrm{etmal} \ldots$. & $\ldots . . .$. \\
R2 (Suhu Kulkas $\left.5^{\circ} \mathrm{C}\right)$ & $59,73 \mathrm{a}$ & $53,06 \mathrm{a}$ & $6,669 \mathrm{~b}$ & $33,87 \mathrm{~b}$ \\
\hline \hline \multicolumn{1}{c}{ UJI F } & $66,80 \mathrm{a}$ & $54,66 \mathrm{a}$ & $8,051 \mathrm{a}$ & $44,80 \mathrm{a}$ \\
\hline P1 (Aluminium Foil) & $6,56^{*}$ & $4,21^{*}$ & $3,91^{*}$ & $1,07 \mathrm{~ns}$ \\
P2 (Kertas) & $66,8 \mathrm{a}$ & $59,2 \mathrm{a}$ & $6,984 \mathrm{~b}$ & $42,40 \mathrm{a}$ \\
P3 (Plastik) & $59,6 \mathrm{~b}$ & $55,2 \mathrm{~b}$ & $6,545 \mathrm{~b}$ & $38,40 \mathrm{a}$ \\
\hline
\end{tabular}

Keterangan : Superskrip yang berbeda pada kolom yang sama, menunjukkan berbeda nyata $(p<0,05)$.

bulan.

Aluminium foil dapat mempertahankan kadar air benih lebih baik dibandingkan wadah simpan kertas dan plastik sehingga menghasilkan potensi tumbuh maksimum yang lebih tinggi. Aluminium foil membatasi pengaruh panas dan oksigen atmosfer pada benih, sehingga mampu mempertahankan kadar air benih dan menghambat respirasi. Sembiring (2009) menyatakan bahwa wadah simpan berfungsi sebagai pengendalian laju respirasi, melindungi benih dari mikroba dan jamur. Wadah simpan aluminium foil menghindarkan benih dari oksigen sehingga tidak mengakibatkan terjadinya respirasi dan akan mempertahankan kadar air benih. Chuansin dkk. (2006) menyatakan bahwa aluminium foil terbukti lebih baik dibanding polypropylene dalam mempertahankan kadar air benih, daya berkecambah maupun vigor benih. Wadah simpan yang baik akan memperkecil terjadinya respirasi pada benih sehingga penurunan kualitas atau kemunduran benih dapat diperlambat. Respirasi yang tidak terjadi menjadikan cadangan makanan dalam benih berupa karbohidrat, lemak, protein dan mineral tidak mengalami degradasi sehingga tetap terjaga sampai dibutuhkan benih untuk tumbuh pada saat dilakukan perkecambahan. Beberapa peneliti terdahulu melaporkan bahwa wadah simpan aluminium foil menghasilkan potensi tumbuh maksimum tertinggi dibanding wadah simpan yang lain pada benih mentimun
(Sumpena, 2012), benih kedelai ( Dewi dkk., 2015).

Hasil potensi tumbuh maksimum yang diperoleh berada dibawah standar mutu yang baik $(>80 \%)$ termasuk hasil terbaik yaitu pada wadah simpan alumunium foil dengan potensi tumbuh maksimum sebesar $66,80 \%$.

\section{Daya berkecambah (DB)}

Hasil analisis ragam menunjukkan bahwa tidak terdapat pengaruh faktor suhu $(\mathrm{P}>0,05)$ terhadap daya berkecambah benih cabai tetapi terdapat pengaruh faktor wadah penyimpanan $(\mathrm{P}<0,05)$ terhadap daya berkecambah benih cabai (Tabel 1). Perlakuan suhu ruangan $28{ }^{\circ} \mathrm{C}$ (R1) tidak berbeda nyata dengan perlakuan suhu kulkas $5{ }^{\circ} \mathrm{C}(\mathrm{R} 2)$ dengan nilai daya berkecambah $53,06 \%$ dan $54,66 \%$. Benih yang disimpan menggunakan aluminium foil (P1) menunjukkan daya berkecambah tertinggi yaitu 58,2\% dan berbeda dengan wadah simpan ketas (P2) dan plastik (P3), tetapi wadah simpan ketas dan plastik tidak berbeda dengan daya berkecambah masingmasing sebesar 55,2\% dan 47,2\%.

Nilai daya berkecambah dipengaruhi oleh jumlah benih yang berkecambah dan jumlah kecambah yang normal dan abnormal. Suhu ruang simpan benih tidak berpengaruh terhadap potensi tumbuh maksimum, artinya bahwa jumlah benih yang berkecambah tidak berbeda, baik kecambah normal maupun abnormal. Menurut Liberty dan 
Taofik (2015) bahwa kecambah normal tercermin pada radikula (akar) primer dan skunder, hipokotil, kotiledon, dan flumula yang terbentuk tumbuh sehat. Nilai daya berkecambah semakin menurun dengan semakin lama waktu penyimpanan, tergantung wadah penyimpanan yang digunakan. Semakin rendah nilai daya berkecambah menunjukkan terjadinya penurunan kualitas benih. Daya berkecambah benih cabai rawit mengalami penurunan setelah disimpan selama 3 bulan baik yang disimpan dengan wadah alumunium foil, plastik dan kertas, tetapi daya berkecambah tertinggi ditunjukkan pada perlakuan wadah alumunium foil. Wadah alumunium foil mampu menghambat penurunan kualitas benih lebih baik dibandingkan dengan wadah simpan lainnya. Perunuranan kualitas benih yang lebih lambat terkait dengan sifat alumonium foil yang yang tidak tembus cahaya, kedap udara dan air. Menurut Dwiari dkk. (2008) bahwa aluminium foil mempunyai sifat fleksibel dan tidak tembus cahaya sehingga baik untuk penyimpanan benih. Hal tersebut diduga karena aluminium foil memiliki sifat kedap udara sehingga dapat meminimalisir masuknya oksigen selama masa simpan sehingga tidak menyebabkan terjadinya respirasi yang dapat mengakibtakan penurunan cadangan makanan pada benih dan menyebabkan terjadinya kemunduran benih.

Hasil daya berkecambah yang diperoleh berada dibawah standar mutu yang baik (80\%) termasuk daya berkecambah pada wadah simpan alumunium foil yang hanya sebesar 58,2 \%.

\section{Kecepatan tumbuh (KcT)}

Hasil analisis ragam kecepatan tumbuh pada Tabel 1 menunjukkan bahwa terdapat pengaruh faktor suhu penyimpanan dan wadah penyimpanan terhadap kecepatan tumbuh benih cabai $(\mathrm{P}<0,05)$ (Tabel 1).

Hasil Uji BNJ pada diperoleh bahwa kecepatan tumbuh benih cabai rawit yang disimpan pada suhu kulkas $5{ }^{\circ} \mathrm{C}$ (R2) sebesar $8,051 \%$ lebih tinggi dibanding yang disimpan pada suhu ruangan $28{ }^{\circ} \mathrm{C}$ (R1) yaitu $6,669 \%$ (Tabel 1).

Aktivitas respirasi sangat kecil pada suhu dingin sehingga dapat mempertahankan kandungan cadangan benih dan tidak mengakibatkan penurunan kualitas benih.
Meskipun suhu ruang penyimpanan tinggi suhu ruangan $28{ }^{\circ} \mathrm{C}$ (R1) tidak menurunkan jumlah benih yang berkecambah, potensi tumbuh maksimum dan daya berkecambah, namun menyebabkan penurunan kecepatan berkecambah sehingga menurunkan kecepatan tumbuh (KcT).

Suhu ruang simpan kulkas menyebabkan kulit benih cabai menjadi keras. Pada suhu kulkas memiliki kelembaban yang tidak tinggi sehingga meminimalisir terjadinya aktivitas enzim pada benih yang mengakibatkan terjadinya respirasi. Purba dkk. (2013) menyatakan bahwa terjadinya respirasi disebabkan oleh aktivitas enzim yang ada dalam benih yang dipengaruhi oleh kadar air dan kelembaban nisbi ruangan yang tinggi.

Hasil Uji BNJ menunjukkan bahwa kecepatan tumbuh benih cabai rawit tertinggi yaitu pada perlakuan wadah simpan plastik (P3) dengan kecepatan tumbuh sebesar 8,551 \%. Pada perlakuan wadah simpan aluminium foil (P1) tidak berbeda nyata dengan perlakuan wadah simpan kertas (P2) dengan kecepatan tumbuh $6,984 \%$ dan 6,545 \% (Tabel 1). Benih yang disimpan pada kemasan plastik memiliki kecepatan tumbuh yang paling tinggi. Terjaganya cadangan makanan dalam benih yang disimpan pada plastik akan mempertahankan kualitas benih cabai rawit yang disimpan. Cadangan makanan atau endosperm yang berada dalam benih akan mempengaruhi kecepatan tumbuh benih, karena dalam aktivitas pertumbuhan benih dibutuhkan cadangan makanan yang digunakan sebagai sumber energi. Lesilolo dan Moriolkossu (2014) menyatakan bahwa kecepatan perkecambahan benih tergantung dari energi yang dimanfaatkan oleh masing-masing benih yang merupakan hasil perombakan dari cadangan makanan yang terdapat dalam endosperm. Hasil kecepatan tumbuh yang diperoleh tergolong cukup baik yaitu pada wadah simpan plastik dengan kecepatan tumbuh sebesar $8,551 \%$ lebih besar dari $2,82 \% /$ etmal.

\section{Indeks vigor (IV)}

Hasil analisis ragam menunjukkan bahwa terdapat pengaruh faktor suhu penyimpanan $(\mathrm{P}<0,05)$ terhadap indeks vigor benih cabai.

Hasil Uji BNJ menunjukkan bahwa benih yang disimpan pada suhu kulkas $5{ }^{\circ} \mathrm{C}$ (R2) menunjukkan indeks vigor yaitu 44,80\% lebih tinggi dibanding suhu ruangan $28{ }^{\circ} \mathrm{C}(\mathrm{R} 1)$ yaitu 
33,87 \%. Perlakuan suhu kulkas $5^{\circ} \mathrm{C}$ (R2) memiliki suhu dan kelembaban yang lebih rendah dibandingkan benih yang disimpan pada suhu ruangan $28^{\circ} \mathrm{C} \quad(\mathrm{R} 1)$. Hal ini menyebabkan penurunan vigor yang lebih lambat dan hasil indeks vigor menjadi lebih tinggi. Menurut Demir dan Mavi (2008), bahwa benih yang disimpan pada kondisi sub optimum (suhu dan RH tinggi) terjadi proses katabolisme yang dapat menurunkan vigor benih. Benih yang disimpan pada suhu ruangan $28{ }^{\circ} \mathrm{C}$ (R1) dengan kelembaban $80 \%$ menyebakan penurunan vigor dan hasil indeks vigor menjadi rendah. Purwanti (2015) menyatakan bahwa benih yang disimpan selama 4 bulan pada ruangan kamar mengakibatkan penurunan vigor benih yang relatif stabil (sangat kecil). Wadah simpan tidak berbeda nyata terhadap hasil indeks vigor. Indeks vigor benih cabai rawit wadah simpan alumunium foil kertas dan plastik masing-masing dengan indeks vigor $42,40 \%, 38,40 \%$ dan $37,20 \%$. Hasil indeks vigor yang diperoleh berada dibawah standar mutu yang baik (80\%) termasuk hasil terbaik yaitu pada suhu simpan kulkas dengan indeks vigor sebesar $42,40 \%$.

\section{Jumlah daun (JD)}

Hasil analisis ragam menunjukkan bahwa tidak terdapat pengaruh faktor suhu dan wadah penyimpanan $(\mathrm{P}>0,05)$ terhadap jumlah daun bibit cabai rawit (Tabel 2). Tanaman cabai pada umur 1 bulan setelah tanam memiliki daun yaitu $3-5$ helai setiap bibit tanaman. Perlakuan suhu dan perlakuan wadah simpan tidak mempengaruhi pertumbuhan vegetatif yaitu parameter jumlah daun. Faktor yang mempengaruhi pertumbuhan vegetatif adalah kondisi benih dan lingkungan.

Suhu simpan benih tidak berpengaruh pada potensi tumbuh maksimum dan daya berkecambah (Tabel 1), berakibat pada proses inisiasi, pembelahan, pertumbuhan dan perkembangan sel daun relatif tidak berbeda, sehingga jumlah daun tidak berbeda.

Wadah atau kemasan benih berpengaruh pada potensi tumbuh maksimum, daya berkecambah, kecepatan tumbuh dan indeks vigor benih (Tabel 1). Wadah simpan berpengaruh terhadap potensi tumbuh maksimum, daya berkecambah, kecepatan tumbuh dan indeks vigor, namun mutu benih tersebut masih di bawah standar yang baik. Pancanigtyas dkk. (2014) menyatakan bahwa

Tabel 2. Jumlah daun (JD), Tinggi Tanaman (TT), Berat Basah (BB), Berat Kering (BK) dan Indeks Vigor Hipotetik (IVH) Bibit Cabai Rawit pada Perlakuan Suhu dan Wadah Penyimpanan yang Berbeda.

\begin{tabular}{|c|c|c|c|c|c|}
\hline & JD & TT & $\mathrm{BB}$ & $\mathrm{BK}$ & IVH \\
\hline UJI F & $0,04^{\mathrm{ns}}$ & $0,46^{\mathrm{ns}}$ & $4,40^{*}$ & $0,15^{\mathrm{ns}}$ & $0,68^{\mathrm{ns}}$ \\
\hline & ....helai.... & ....cm.... & ....g.... & $\ldots . \mathrm{g} \ldots$ & $\ldots . . \% \ldots$ \\
\hline R1 ( Suhu Ruang $28^{\circ} \mathrm{C}$ ) & $4,933 \mathrm{a}$ & $3,380 \mathrm{a}$ & $1,346 \mathrm{~b}$ & $0,0138 \mathrm{a}$ & $0,701 \mathrm{a}$ \\
\hline R2 (Suhu Kulkas $5^{\circ} \mathrm{C}$ ) & $4,907 \mathrm{a}$ & $3,459 \mathrm{a}$ & $1,543 \mathrm{a}$ & $0,0142 \mathrm{a}$ & $0,705 \mathrm{a}$ \\
\hline UJI F & $3,17^{\mathrm{ns}}$ & $0,91^{\mathrm{ns}}$ & $3,39^{*}$ & $3,65^{*}$ & $2,2^{\mathrm{ns}}$ \\
\hline P1 (Aluminium Foil) & $5,220 \mathrm{a}$ & $3,500 \mathrm{a}$ & $0,108 \mathrm{a}$ & $0,0151 \mathrm{a}$ & $0,735 \mathrm{a}$ \\
\hline P2 (Kertas) & $4,880 \mathrm{a}$ & $3,434 \mathrm{a}$ & $0,097 \mathrm{~b}$ & $0,0144 \mathrm{~b}$ & $0,723 \mathrm{a}$ \\
\hline P3 (Plastik) & $4,660 \mathrm{a}$ & $3,324 \mathrm{a}$ & $0,082 \mathrm{~b}$ & $0,0123 \mathrm{~b}$ & $0,651 \mathrm{a}$ \\
\hline
\end{tabular}

Keterangan : Superskrip yang berbeda pada kolom yang sama menunjukkan berbeda nyata $(p<0,05)$.

\section{Pertumbuhan Bibit Cabai Rawit}

Pertumbuhan bibit cabai rawit meliputi jumlah daun (JD), tinggi tanaman (TT), berat basah (BB), berat kering (BK) dan indeks vigor hipotetik (IVH) bibit. pemunculan kecambah di atas pemukaan tanah merupakan faktor yang mencerminkan vigor suatu bibit. Hal tersebut menyebakan jumlah daun bibit yang ditanam tidak berbeda. Respon benih dengan potensi tumbuh maksimum rendah dan daya berkecambah rendah kurang mampu beradaptasi 
sehingga pertumbuhannya rendah. Utomo (2006) menyatakan bahwa benih dengan kualitas yeng tidak baik setelah berkecambah kurang mampu merespon kondisi lingkungan dengan baik sehingga hasil pertumbuhannya rendah. Faktor lingkungan berpengaruh besar terhadap pertumbuhan benih salah satunya adalah menghasilkan daun. Rusmin dkk. (2014) menyatakan bahwa selain faktor air, cahaya dan oksigen suhu merupakan salah satu faktor syarat perkecambahan yang sangat penting yang mempengaruhi kapasitas dan kecepatan berkecambah, mematahkan dormansi primer dan sekunder dan mendorong terjadinya dormansi sekunder.

\section{Tinggi tanaman (TT)}

Hasil analisis ragam menunjukkan bahwa tidak terdapat pengaruh faktor suhu penyimpanan dan wadah penyimpanan terhadap tinggi tanaman cabai $(\mathrm{P}>0,05) \quad($ Tabel 2). Tinggi tanaman merupakan respon dari pertumbuhan tanaman untuk mendapatkan cahaya matahari. Tinggi tanaman cabai rawit dipengaruhi oleh faktor internal yaitu gen dan faktor eksternal yaitu lingkungan yang bisa berupa sinar matahari. Selain itu cadangan makanan dalam benih akan mempengaruhi kemampuan benih untuk tumbuh menjadi tanaman

Penyebab tidak adanya pengaruh suhu dan wadah simpan terhadap tinggi tanaman karena tanaman cabai merupakan jenis tanaman dari gen yang sama sehingga kemungkinan pertumbuhan tingginya akan sama. Faktor lain yang mendukung adalah penyinaran matahari yang sama pada semua perlakuan menyebabkan tinggi tanaman yang tidak berbeda nyata. Immawati dkk. (2013) menyatakan bahwa tinggi bibit dikendalikan oleh faktor genetik, selain itu dipengaruhi juga oleh faktor lingkungan. Faktor lain yang mempengaruhi tinggi tanaman cabai adalah pemberian dosis pupuk yang sama pada semua perlakuan menyebabkan tanaman cabai memiliki tinggi yang sama. Wasis dan Fathia (2010) menyatakan bahwa perkembangan dan pertambahan tinggi tanaman banyak dipengaruhi oleh kelancaran penyerapan hara yang langsung diangkut dan diolah di daun dalam proses fotosintesis.

\section{Berat basah (BB)}

Hasil analisis ragam menunjukkan bahwa terdapat pengaruh perlakuan suhu dan wadah simpan $(\mathrm{P}>0,05)$ terhadap berat basah tanaman cabai. Hasil Uji BNJ pada Tabel 2 menunjukkan bahwa benih yang disimpan pada suhu kulkas $5{ }^{\circ} \mathrm{C}$ (R2) menunjukkan BB sebesar 1,547 $\mathrm{g}$ yang lebih tinggi dari perlakuan suhu ruang $28{ }^{\circ} \mathrm{C}$ (R1) sebesar $1,346 \mathrm{~g}$. Hal yang mempengaruhi berat tanaman adalah tinggi tanaman dan jumlah daun. Pada suhu dingin benih akan terhindar dari panas yang dapat mempengaruhi kadar air dan kelembaban benih. Benih yang kadar air dan kelembabannya terjaga akan terhindar dari proses respirasi yang dapat menurunkan cadangan makanan dalam benih sehingga kualitasnya tidak dapat dipertahankan. Benih yang memiliki kualitas baik pertumbuhannya akan baik sehingga menghasilkan akar, daun dan batang yang normal dan berpengaruh pada hasil berat basah tanaman. Darmawan dkk. (2014) menyatakan bahwa benih yang memiliki nilai vigor dan viabilitas yang tinggi dapat menghasilkan produksi yang lebih baik karena cadangan makanan yang tersedia lebih banyak.

Hasil Uji BNJ pada Tabel 2 menunjukkan bahwa benih yang disimpan pada wadah simpan alumunium foil (P1) menunjukkan BB sebesar 0,1089 g yang lebih tinggi dari perlakuan wadah simpan kertas (P2) dan plastik (P3) dengan berat sebesar 0,0977 g dan 0,0827 g. Purba dkk. (2013) menyatakan bahwa kemasan aluminium foil memiliki kelebihan yaitu kedap udara sehingga kelembaban pada benih selama penyimpanan tetap terjaga. Pada tempat penyimpanan yang tidak kedap udara kadar airnya menjadi tinggi akibat dari benih yang mengadakan keseimbangan kadar air dengan udara sekitarnya, sedangkan tempat penyimpanan yang kedap udara mampu mempertahankan kadar air benih tetap rendah. Alumunium foil memiliki kerapatan yang lebih tinggi dibandingkan plastik dan kertas sehingga dapat melindungi benih dari udara luar yang masuk. Rahardjo (2012) menyatakan bahwa penggunaan wadah simpan yang berpori atau berlubang menyebabkan udara dari luar dan uap air masuk kedalam wadah simpan sehingga kadar air benih semakin tinggi dan laju respirasi meningkat. 


\section{Berat kering (BK)}

Hasil analisis ragam menunjukkan bahwa tidak terdapat pengaruh faktor suhu penyimpanan $(\mathrm{P}>0,05)$ terhadap berat kering tanaman cabai rawit tetapi terdapat pengaruh faktor wadah penyimpanan $(\mathrm{P}<0,05)$ terhadap berat kering tanaman cabai. Hasil Uji BNJ menunjukkan bahwa benih yang disimpan pada alumunium foil mempunyai berat kering sebesar $0,0174 \mathrm{~g}$ lebih tinggi dari kertas dan plastik dengan berat kering sebesar $0,0135 \mathrm{~g}$ dan $0,0113 \mathrm{~g}$.

Hasil berat kering akan mengikuti hasil dari berat basah. Prasetyo (2014) menyatakan bahwa hasil berat basah cabai yang tinggi menghasilkan hasil berat kering yang tinggi pula. Wadah simpan alumunium foil memiliki kelebihan dapat mempertahankan kualitas benih lebih baik dibandingkan plastik dan kertas. Kualitas benih yang terjaga akan mempengaruhi hasil pertumbuhan benih setelah ditanam. Benih akan tumbuh menjadi tanaman yang baik sehingga akan mempengaruhi berat kering tanaman. Franklin dkk. (2008) menyatakan bahwa berat kering biomassa tanaman sangat dipengaruhi oleh proses pertumbuhan dan diferensiasi sel tanaman. Proses diferensiasi tanaman mempunyai tiga syarat yaitu hasil asimilasi yang tersedia dalam keadaan berlebihan untuk dapat dimanfaatkan pada kegiatan metabolik, suhu yang menguntungkan, dan terdapat sistem enzim yang tepat untuk memperantarai proses diferensiasi. Apabila dari ketiga persyaratan tersebut dapat terpenuhi, maka akan terjadi penebalan dinding sel, deposit dari sebagian sel, pengerasan protoplasma. Cadangan makanan dalam benih yang terjaga akan menghasilkan pertumbuhan tanaman yang baik salah satunya adalah pertumbuhan tinggi tanaman. Darmawan dkk. (2014) menyatakan bahwa keberhasilan perkecambahan biji dipengaruhi oleh faktor internal biji yaitu kandungan endosperm yang berhubungan dengan kemampuan biji melakukan imbibisi dan ketersediaan sumber energi kimiawi potensial bagi biji.

\section{Indeks vigor hipotetik (IVH)}

Hasil analisis ragam menunjukkan bahwa tidak terdapat pengaruh faktor suhu penyimpanan dan wadah penyimpanan $(\mathrm{P}>0,05)$ terhadap indeks vigor hipotetik tanaman cabai (Tabel 2). Indeks vigor hipotetik menunjukkan kemampuan benih untuk tumbuh menjadi tanaman muda.

Semakin tinggi nilai jumlah daun, tinggi tanaman, berat basah dan berat kering bibit maka akan menghasilkan nilai indeks hipotetik yang tinggi. Nilai indeks hipotetik yang tinggi menunjukkan tanaman dapat tumbuh normal meskipun benih telah disimpan dalam waktu yang lama. Nautiyal dkk. (2010) menyatakan bahwa indeks vigor hipotetik memberi gambaran tentang pendugaan kemampuan benih untuk dapat tumbuh menjadi tanaman yang normal meskipun keadaan biofisik lapangan produksi adalah suboptimum atau setelah benih melampaui kurun waktu simpan yang lama. Immawati dkk. (2013) menyatakan bahwa pengujian vigor hipotetik meliputi pertumbuhan bibit dilihat dari luas daun, tinggi bibit, berat kering bibit, jumlah daun, diameter batang serta umur bibit dan kemapuan benih untuk tumbuh menjadi bibit dapat diketahui dengan melakukan pengujian vigor hipotetik.

\section{KESIMPULAN}

Berdasarkan hasil penelitian dapat disimpulkan bahwa penyimpanan benih cabai rawit selama 3 bulan, pada suhu ruang penyimpanan rendah $\left(5^{\circ} \mathrm{C}\right)$ menghasilkan kecepatan tumbuh dan indeks vigor lebih besar dibanding suhu ruangan yang lebih tinggi $\left(28^{\circ} \mathrm{C}\right)$, yaitu sebesar $8,051 \% /$ etmal dan $44,80 \%$ \%/etmal dibanding 6,669 dan 33,87\%. Namun potensi tumbuh maksimum dan daya berkecambah tidak berbeda. Kemasan alumunium foil menghasilkan potensi tumbuh maksimum dan daya berkecambah sebesar $66,8 \%$, dan $59,2 \%$, lebih tinggi dibanding kemasan plastik sebesar59,6 \% dan 55,2\% dan kertas sebesar $54,4 \%$ dan $47,2 \%$, namun tidak berbeda kecepatan tumbuh dan indeks vigor.Suhu ruang penyimpanan rendah $\left(5^{\circ} \mathrm{C}\right)$ tidak dapat mempertahankan kualitas benih secara maksimal karena 4 parameter tersebut masih dibawah standar kualitas benih.

Suhu ruang penyimpanan rendah $\left(5^{\circ} \mathrm{C}\right)$ menghasilkan berat basah dan berat kering lebih besar dibanding suhu ruangan yang lebih tinggi $\left(28{ }^{\circ} \mathrm{C}\right)$, yaitu sebesar $1,346 \mathrm{~g}$ dan 0,0138 dibanding $1,543 \mathrm{~g}$ dan $0,0142 \mathrm{~g}$. Namun jumlah daun, tinggi bibit dan indeks vigor hipotetiktidak berbeda. Kemasan aluminium foil menghasilkan berat basah dan berat keringsebesar $0,108 \mathrm{~g}$ dan 
$0,0151 \mathrm{~g}$ lebih tinggi dibanding kemasan plastik sebesar $0,082 \mathrm{~g}$ dan $0,0123 \mathrm{~g}$ dan kertas sebesar 0,097 gdan 0,0144 g. Namun jumlah daun, tinggi bibit dan indeks vigor hipotetik tidak berbeda.

\section{DAFTAR PUSTAKA}

Alif, S M. 2017. Kiat Sukses Budidaya Cabai Rawit. Bio Genesis. Yogyakarta.

Chuansin, S., S. Vearasilp, S. Srichuwong and E. Pawelzik. 2006. Selection of packaging materials for soybean seed storage. Conference on International Agricultural Research for Development. University of Bonn.

Darmawan, A. C., Respatijarti dan L. Soetopo. 2014. Pengaruh tingkat kemasakan benih terhadap pertumbuhan dan produksi cabai rawit (Capsicum frutescent L.) Varietas comexio. J. Produksi Tanaman, Vol. 2( 4) : 339-346.

Demir, I., K. Mavi. 2008. Seed vigor evaluation of cucumber

(Cucumis sativus L.) seeds in relation to seedling emergence. Seed Sci. Tech. Vol.1 (1) :19-25.

Dewi, F. O., Sumadi dan D. S. Sobarna. 2015. Pengaruh berbagai jenis kemasan dan desikan terhadap viabilitas, vigor benih kedelai (Glycine $\max$ (L.) Merr.) dan perkembangan hama Callosobruchus maculatus selama periode simpan tiga bulan. J. Agric. Sci., Vol.2 (1) : 20-30.

Dwiari, S. R., D. D. Asadayanti, Nurhayati., M. Sofyaningsih, S. F. A. R. Yudhanti dan I. B. K. W. Yoga. 2008. Teknologi Pangan. Jilid 2. Direktorat Pembinaan Sekolah Menegah Kejuruan. Jakarta.

Ekowahyuni, L. P., S. H. Sutjahjo, S. Sujiprihati, M. R. Suhartanto, dan M. Syukur. 2012. Metode pengusangan cepat untuk pengujian vigor daya simpan benih cabai (Capsicum annuиm L.). J. Agron. Indonesia. Vol.40 (2) : $132-138$.
Franklin P.G., R. Brent P., Roger L.M. 2008. Fisiologi Tanaman Budidaya. Penerbit Universitas Indonesia (UI Press). Jakarta.

Indartono. 2011. Pengkajian suhu ruang penyimpanan dan teknik pengemasan terhadap kualitas benih kedelai. J. Gema Teknologi, Vol. 16 (3) : 158-163.

ISTA. 2007. International Rule for Seed Testing Edition 2007. International Seed

Immawati, D. R, S. Purwanti dan D. Prajitno. 2013. Daya simpan benih kedelai hitam (Glycine max (L) Merrill) hasil tumpangsari dengan sorgum manis (Shorgum bicolor (L) Moench). J. Vegetalika. Vol.2 (4) : 25-34.

Kartono. 2004. Teknik penyimpanan benih kedelai varietas Wilis pada kadar air dan suhu penyimpanan yang berbeda. Bul Tek Per. Vol.9 (2) : 79-82.

Lesilolo, K. M dan B. Moriolkossu. 2014. Pengaruh perbedaan tingkat kematangan buah dari dua varietas cabe (Capsicum frutescens, L.) Terhadap Viabilitas dan Vigor Benih. J. Budidaya Pertanian. Vol.10 (1) : 10-13.

Nautiyal, P.C., Misra, J.B. and Zala, P.V., 2010. Influence of seed maturity stages on germinability and seedling vigor in groundnut. J. of SAT Agricultural Research. Vol.8 (5) : 1-10.

Pancaningtyas S., T. I. Santoso dan Sudarsianto. 2014. Studi perkecambahan benih kakao melalui metode perendaman. Pellita Perkebunan, Vol. 30 (3) : 190-197.

Prasetyo, R. 2014. Pemanfaatan berbagai sumber pupuk kandang sebagai sumber $\mathrm{N}$ dalam budidaya cabai merah (Capsicum annum L.) di tanah berpasir. Planta Tropika J. of Agro Science Vol.2 (2) : 125 - 132.

Purba H. W. S, F. E. Sitepu dan Haryati. 2013. Viabilitas benih rosela (hibiscus sabdariffa 1.) Pada berbagai kadar air awal dan 
kemasan benih. J. Online Agroekoteknologi. Vol.1 (2) : 318-326.

Purwanti, M. D. 2015. Efektifitas kemasan dan suhu ruang simpan terhadap daya simpan benih kedelai (Glycine max (L.) Meirril). J. Agro science, Vol.3 (1) : 1-7.

Rahayu, E dan e. Widajati. 2007. Pengaruh kemasan, kondisi ruang simpan dan periode simpan terhadap viabilitas benih caisin (Brassica chinensis L.). Bul. Agron. Vol.35 (3): $191-196$.

Rukmana. H. R. 2006. Usaha Tani Cabai Rawit. Kanisius. Yogyakarta.

Rusmin, D., F. Suwarno, I. Darwati Dan S. Ilyas. 2014. Pengaruh suhu dan media perkecambahan terhadap viabilitas dan vigor benih purwoceng untuk menentukan metode pengujian benih. Bul. Littro. 25(1): $45-52$.

Sembiring, N. N. 2009. Pengaruh Jenis Bahan Pengemas terhadap Kualitas Produk Cabai Merah (Capsicum annum L.) Segar Kemasan Selama Penyimpanan Dingin (Tesis). Universitas Sumatera Utara. Medan.

Sekretariat Jenderal Kementerian Pertanian. 2016. Outlook Sub Sektor Komoditas Pertanian Sub Sektor Hortikultura. Pusat Data dan Sistem Informasi Pertanian Kementerian Pertanian 2016.

Silvia M, H Susanti, Samharinto dan Gt. M. S. Noor. 2016. Produksi tanaman cabe rawit (Capsicum frutescent L.) di tanah ultisol menggunakan bokashi sampah organik rumah tangga dan NPK. Enviro Scienteae. Vol.12 (1) : 22-27.

Sumpena, U. 2012. Pengaruh kemasan dan waktu penyimpanan terhadap kemampuan berkecambah benih mentimun. J. Ilmu-ilmu Pertanian, Mediagro. Vol.8 (1): 18 - 25.

Triadi D., T. Chairunnisa dan S. Silitonga. 2013. Respons ketahanan lima varietas cabai merah (Capsicum annum L.) terhadap berbagai konsentrasi garam nacl melalui uji perkecambahan. J. Online Agroekoteknologi Vol.1 (3) : 794 - 804.

Tuwu, E. R, G. A. K. Sutarti dan Suaib. 2012. Pengaruh kadar air benih dan jenis kemasan terhadap vigor benih sorgum (Sorgum bicolor 1. Moench) dalam enam bulan masa simpan. J. Berkala Penelitian Agronomi. Vol.1 (2): 184-193.

Utomo, B. 2006. Ekologi Benih. USU Repository, Medan.

Wasis, B., dan Fathia, N.. 2010. Pengaruh Pupuk NPK Terhadap Pertumbuhan Semai Gmelina (Gmelina arbores Roxb.) Pada Media Bekas Tambang Emas (Tailing). Bogor. Departemen Silvikultur, Fakulltas Kehutanan, IPB.

Yuniarti, N. dan D. Djaman. 2015. Teknik pengemasan yang tepat untuk mempertahankan viabilitas benih bakau (Rhizophora apiculata) selama penyimpanan. Pros sem nas masy biodiv indon. Vol.1 (6): 1438-1441. 